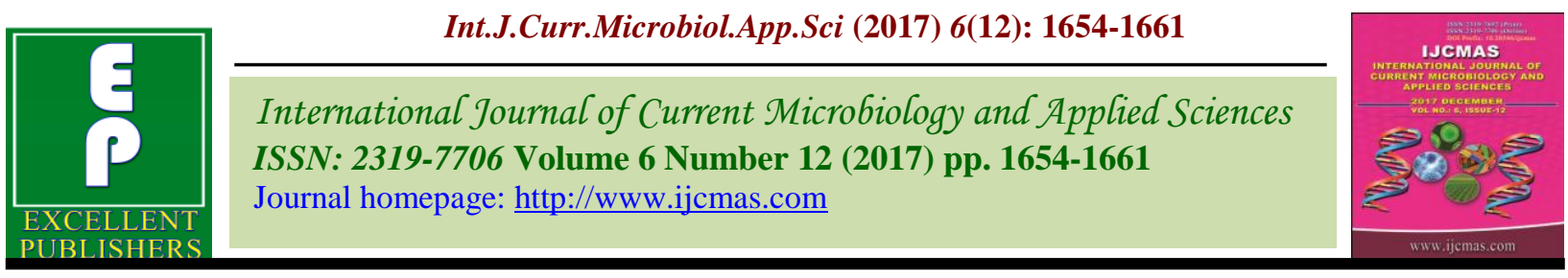

Original Research Article

https://doi.org/10.20546/ijcmas.2017.612.186

\title{
Changing Pattern of Area, Production and Productivity of Principal Crops in Haryana, India
}

\author{
Sunita*, Sanjay, Kavita, Jitender Kumar Bhatia and V.P. Mehta \\ Department of Agricultural Economics, Chaudhary Charan Singh Haryana Agricultural \\ University, Hisar, Haryana-125004, India \\ *Corresponding author
}

A B S T R A C T

Keywords

Area, Production pattern, Growth rates.

Article Info

Accepted:

12 October 2017

Available Online:

10 December 2017
The study was based on secondary data collected from various issues of Statistical Abstracts of Haryana and other published and unpublished sources. The results revealed that with the passage of time, there has been a substantial change in the cropping pattern in the state. In overall study period (1993-2013) the area, production and productivity of food grains has shown increasing trend with a compound annual growth rate of $0.56,2.56$ and 1.93 per cent per annum while for pulses all these values were in negative. Average area has increased only in case of rice, wheat and barley while the area under other crops like jowar, bajra, maize, cotton, sugarcane, etc. declined during the study period. The cropping pattern has skewed towards rice-wheat cultivation. The decline in the growth of area for pearlmillet and sugarcane is due to shift of area towards paddy while decrease in area of gram is due to shift of area towards wheat.

\section{Introduction}

Haryana is one of the smallest States in India with 4.4 million hectares of land, forming 1.34 percent of the total geographical area of the country. Nearly 80 percent of the total geographical area of the State is under cultivation of which about 84 percent is irrigated with cropping intensity of 184 percent (HSAP, i.e., Haryana State Agriculture Policy).

The State has the distinction of attaining food self-sufficiency in the shortest period after its emergence. Haryana state has the prime position of being one of the major contributors to the central food-grain pool of India (Raj and Gupta, 2015).
By 2025, per capita consumption of pulses, edible oils, fruits, vegetables and milk is estimated to increase by 28 to 75 percent (Haryana State Agriculture Policy). A remarkable growth in food grains production has been achieved in Haryana since its creation in 1966-67. The wheat and paddy crops have played a major role in pushing up the agricultural production in the State. Declining total factor productivity (TFP), rising cost of production and increasing concern on quality of food, increasing international competition due to globalization of agriculture, more area under cereal based (rice-wheat) cropping system, declining acreage under leguminous crops, degrading 
soil fertility/soil health with low organic matter, sulphur, potash and micronutrients are, indeed, the emerging threats for the State agriculture.

In view of shrinking agricultural land and operational land holdings which are attributable to the expansion of urban areas and high growth rate of population along with the changes in consumer food habits, the farmers are straining to include or substitute additional high value crops in the cropping system (Singh, 2011). In view of degrading natural resources (soil, water), the state has already banned cultivation of summer rice. Other options to replace paddy like promoting maize cultivation both in kharif and spring should be explored. Also, direct seeded rice/aerobic basmati rice should be encouraged. It will also be necessary to demarcate areas under rice and wheat (in terms of hybrid, basmati, organic, etc.) so as to sustain long term use of natural resources.

The decision to diversify crops is a particularly challenging one for farmers in semi-arid systems. Semi-arid systems can exhibit greater variability in annual precipitation in areas that are marginal for agricultural production (Mc Cord et al., 2015).

\section{Materials and Methods}

The inferences drawn from this study are based on secondary data collected from various issues of Statistical Abstracts of Haryana, published by the Directorate of Economics and Statistics, Government of Haryana and the Agricultural Statistics at a Glance, published by Ministry of Agriculture, Government of India for the period 1993-94 to 2013-14. Data for land utilization in Haryana was collected for the years 1993-94, 1998-99, 2003-04, 2008-09 and 2013-14. Compound growth rates for area, production and productivity were also computed using various statistical techniques.

\section{Results and Discussion}

\section{Changes in land use pattern}

According to village papers, the total area of Haryana was 4374 thousand hectares in 199394. Agriculture is still the main occupation of the rural people and land is a limiting factor so far as cultivation is concerned, the pattern of land use in the state in different periods is depicted in Table 1.

Net area sown has decreased slightly from $80.3 \%$ in $1993-94$ to $79.9 \%$ in $2013-14$ or it is almost stagnant. Area sown more than once has increased from 2302 to 2974 thousand hectares, i.e., from 52.6 to $67.9 \%$. But the growth rate of forest area has decreased sharply shifting from 167 to only 35 thousand hectares. In 2013, the area under forest was just $0.80 \%$ of total area. This signifies deforestation conditioned by population pressure and accompanied demand for cultivable land. An increasing trend has followed by land put to non-agricultural uses and barren and uncultivable land from 322 to 537 and 91 to 125 thousand hectares respectively. The reason for increasing barren area can be some environmental degradation as a result of non-judicious use of modern technologies. The area under current fallow has decreased from 209 to 101 thousand hectares which indicates increment in bringing additional uncultivated land into agricultural uses or some other uses.

\section{Cropping pattern}

It is evident from the Table 2 that with the passage of time, there has been a substantial change in the cropping pattern of the state. Area has increased only in case of rice, wheat and barley while the area under other crops 
like jowar, bajra, maize, cotton, sugarcane, etc. declined during the study period. The area under total pulses declined sharply from 440.5 in the period 1993-98 to 133.68 thousand hectares in the period 2008-13. It shows that there is a great need for diversification of crops. With the expansion of irrigation facilities, extensive use of improved/HYV seeds, fertilizers, plant protection chemicals and mechanical power, there had been a shift of area in favour of more remunerative and less risky crops like wheat and paddy.

The decrease in area of other crops like bajra, maize, gram, sugarcane, sunflower, etc. was due to risks associated with them, which may be production risk or price risk.

Compound growth rates of area, production and productivity for different crops in the state are presented in Table 2, 3 and 4, respectively. From the Table 2, it is evident from the estimated compound growth rate of area that the area under rice, wheat and sugarcane has grown at significantly positive rate in the first period (1993-94 to 2003-04). Contrarily, the area under coarse cereals (jowar, maize and barley) had declined in the same period. Enhanced pay-off from superior cereals (rice and wheat) as a result of popularization of yield raising technologies coupled with the policy of assured market clearance at remunerative price pursued during that time is responsible for the diversion of area towards them from technologically lagging coarse cereals and pulses. The overall positive growth rate of area, i.e., from 1993-94 to 2013-14 has occurred in case of rice, wheat, barley and ultimately total cereals. Total food grains showed a significant positive growth rate of $0.56 \%$, even though this group includes pulses also which showed a negative growth rate but the contribution of cereals is more than pulses, that's why, overall food grains has a positive growth rate. Sugarcane and cotton showed overall negative growth rate of area significantly during the study period (Figs 1 and 2).

Table.1 Land utilization in Haryana (Area in 000' hectares)

\begin{tabular}{|c|c|c|c|c|c|c|}
\hline Sr. No. & Particulars & 1993-94 & 1998-99 & 2003-04 & 2008-09 & 2013-14 \\
\hline \multirow[t]{2}{*}{1} & Net area sown & 3513 & 3628 & 3534 & 3576 & 3497 \\
\hline & & $(80.3)$ & $(82.9)$ & $(80.7)$ & $(81.7)$ & $(79.9)$ \\
\hline \multirow[t]{2}{*}{2} & Area sown more than once & 2302 & 2692 & 2854 & 2924 & 2974 \\
\hline & & $(52.6)$ & $(61.5)$ & $(65.2)$ & $(66.8)$ & $(67.9)$ \\
\hline 3 & Total cropped area & 5815 & 6320 & 6388 & 6500 & 6471 \\
\hline \multirow[t]{2}{*}{4} & Forest & 167 & 115 & 45 & 39 & 35 \\
\hline & & $(3.81)$ & $(2.62)$ & $(1.02)$ & $(0.89)$ & $(0.80)$ \\
\hline \multirow[t]{2}{*}{5} & $\begin{array}{l}\text { Land put to non- } \\
\text { agricultural uses }\end{array}$ & 322 & 350 & 432 & 470 & 537 \\
\hline & & $(7.36)$ & $(8.00)$ & $(9.87)$ & $(10.7)$ & $(12.2)$ \\
\hline \multirow[t]{2}{*}{6} & $\begin{array}{l}\text { Barren and uncultivable } \\
\text { land }\end{array}$ & 91 & 89 & 100 & 103 & 125 \\
\hline & & $(2.08)$ & $(2.03)$ & $(2.28)$ & $(2.35)$ & $(2.85)$ \\
\hline \multirow[t]{2}{*}{7} & Current fallows & 209 & 143 & 192 & 105 & 101 \\
\hline & & $(4.77)$ & $(3.26)$ & $(4.38)$ & $(2.40)$ & $(2.31)$ \\
\hline \multirow[t]{2}{*}{8} & Total area & 4374 & 4374 & 4374 & 4374 & 4374 \\
\hline & & (100) & (100) & (100) & (100) & (100) \\
\hline
\end{tabular}

Note: Figures in parentheses are in percentages except total cropped area as it is more than total area. 
Table.2 Compound growth rates of area of major crops (per cent per annum)

\begin{tabular}{|l|c|c|c|}
\hline Crops & $\mathbf{1 9 9 3 - 2 0 0 3}$ & $\mathbf{2 0 0 3 - 1 3}$ & $\mathbf{1 9 9 3 - 2 0 1 3}$ \\
\hline Rice & $2.644^{*}$ & $2.435^{*}$ & 2.10 \\
\hline Jowar & $-1.976^{*}$ & -5.744 & -3.97 \\
\hline Bajra & 0.030 & -3.516 & -0.75 \\
\hline Maize & $-6.543^{*}$ & $-6.794^{*}$ & -5.56 \\
\hline Wheat & $2.122^{*}$ & 0.971 & 1.27 \\
\hline Barley & $-5.542^{*}$ & 4.921 & 0.19 \\
\hline Total cereals & $1.704^{*}$ & 0.681 & 1.05 \\
\hline Gram & $-18.108^{*}$ & $-6.595^{*}$ & -8.40 \\
\hline Total Pulses & $-14.077^{*}$ & -6.684 & -6.71 \\
\hline Total Food grains & 0.485 & 0.462 & $0.56^{*}$ \\
\hline Rapeseed mustard & -0.424 & $-2.702^{*}$ & -0.08 \\
\hline Total Oilseeds & -1.093 & $-2.886^{*}$ & -0.34 \\
\hline Cotton & -1.651 & 0.074 & $-0.76^{*}$ \\
\hline Sugarcane & $2.811^{*}$ & $-4.436^{*}$ & $-2.65^{*}$ \\
\hline
\end{tabular}

Note: *Significant at 5\% level of probability

Table.3 Compound growth rate of production of major crops (per cent per annum)

\begin{tabular}{|l|c|c|c|}
\hline Crops & $\mathbf{1 9 9 3 - 2 0 0 3}$ & $\mathbf{2 0 0 3 - 1 3}$ & $\mathbf{1 9 9 3 - 2 0 1 3}$ \\
\hline Rice & $2.943^{*}$ & $2.807^{*}$ & 3.45 \\
\hline Jowar & $-2.780^{*}$ & 1.996 & $1.87^{*}$ \\
\hline Bajra & $2.412^{*}$ & 1.584 & $3.24^{*}$ \\
\hline Maize & -2.856 & $-5.083^{*}$ & -3.80 \\
\hline Wheat & 3.331 & $3.381^{*}$ & 2.51 \\
\hline Barley & $-5.071^{*}$ & $8.966^{*}$ & $2.09^{*}$ \\
\hline Total cereals & $3.147^{*}$ & $3.225^{*}$ & 2.80 \\
\hline Gram & $-20.94^{*}$ & -2.403 & $-8.23^{*}$ \\
\hline Total Pulses & $-17.94^{*}$ & 1.335 & $-5.20^{*}$ \\
\hline Total Food grains & $2.599^{*}$ & $3.166^{*}$ & 2.56 \\
\hline Rapeseed mustard & 1.232 & 1.768 & $1.81^{*}$ \\
\hline Total Oilseeds & 0.166 & 1.523 & 1.40 \\
\hline Cotton & -2.316 & 2.869 & $4.0^{*}$ \\
\hline Sugarcane & $3.031^{*}$ & -2.240 & -0.96 \\
\hline
\end{tabular}

Note:* Significant at $5 \%$ level of probability 
Table.4 Compound growth rates of yield of major crops (per cent per annum)

\begin{tabular}{|l|c|c|c|}
\hline Crops & $\mathbf{1 9 9 3 - 2 0 0 3}$ & $\mathbf{2 0 0 3 - 1 3}$ & $\mathbf{1 9 9 3 - 2 0 1 3}$ \\
\hline Rice & 0.29 & 0.36 & $1.32^{*}$ \\
\hline Jowar & -1.44 & 8.63 & 5.89 \\
\hline Bajra & 2.38 & 5.29 & 4.03 \\
\hline Maize & $3.97^{*}$ & 1.57 & $1.96^{*}$ \\
\hline Wheat & $1.18^{*}$ & 2.38 & 1.22 \\
\hline Barley & 0.49 & 3.76 & 1.87 \\
\hline Total Cereals & 1.41 & 1.76 & 1.48 \\
\hline Gram & -3.46 & 4.45 & 0.17 \\
\hline Total Pulses & $-4.51^{*}$ & 1.34 & -0.45 \\
\hline Total Food grains & $2.10^{*}$ & $2.50^{*}$ & 1.93 \\
\hline Rapeseed mustard & 2.16 & $4.62^{*}$ & $2.07 *$ \\
\hline Total Oilseeds & 1.27 & $4.51^{*}$ & $1.75^{*}$ \\
\hline Cotton & $6.82^{*}$ & 1.94 & 6.96 \\
\hline Sugarcane & 0.21 & $2.26^{*}$ & 1.72 \\
\hline Note: Signifint at $5 \%$ & & \\
\hline
\end{tabular}

Note:* Significant at $5 \%$ level of probability

Fig.1 Trends in area of rice, wheat and cotton in Haryana

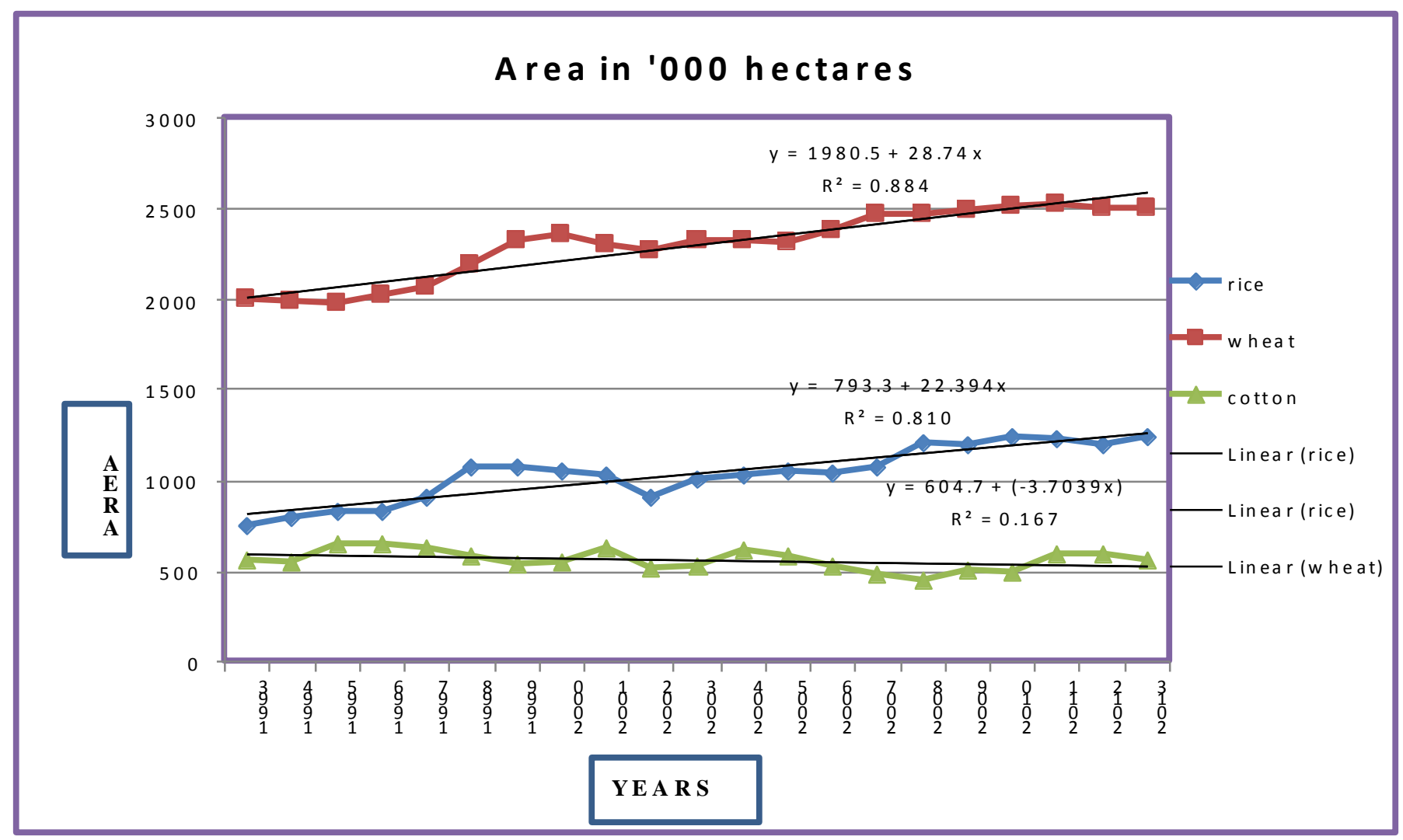


Fig.2 Trends in area of total pulses, total oilseeds and sugarcane in Haryana

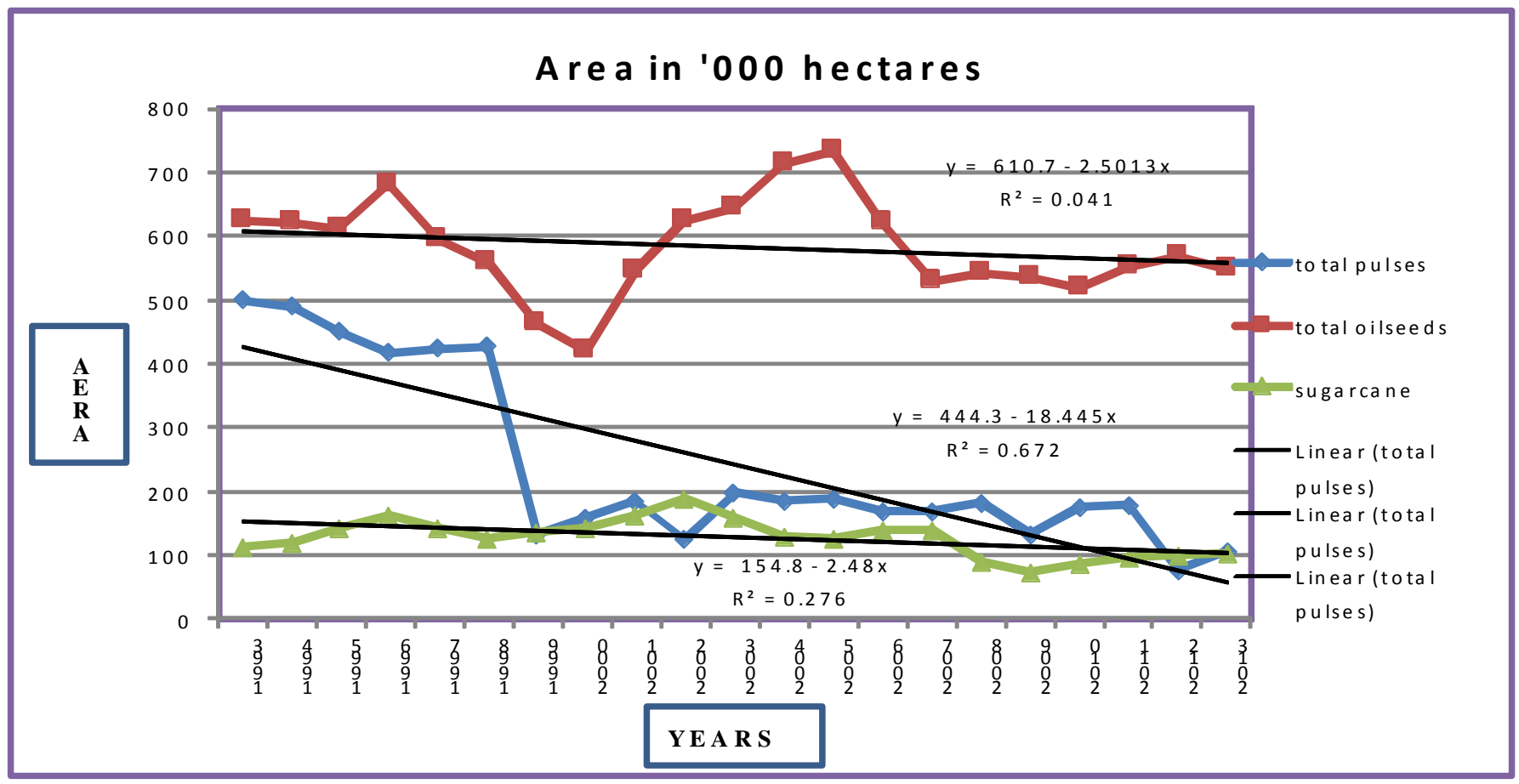

Fig.3 Trends in production of rice, wheat and cotton in Haryana

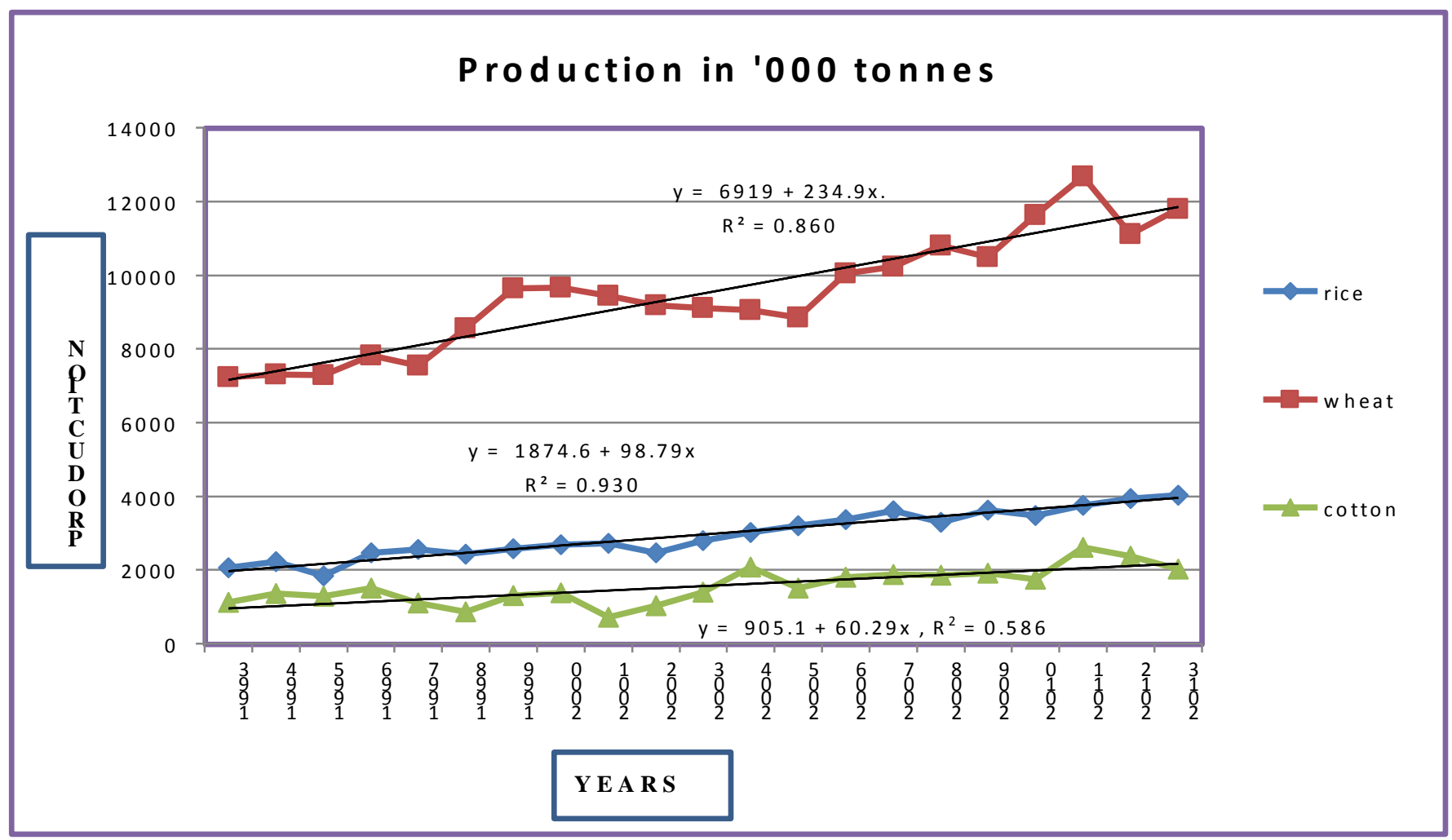


Fig.4 Trends in production of total pulses and total oilseeds in Haryana

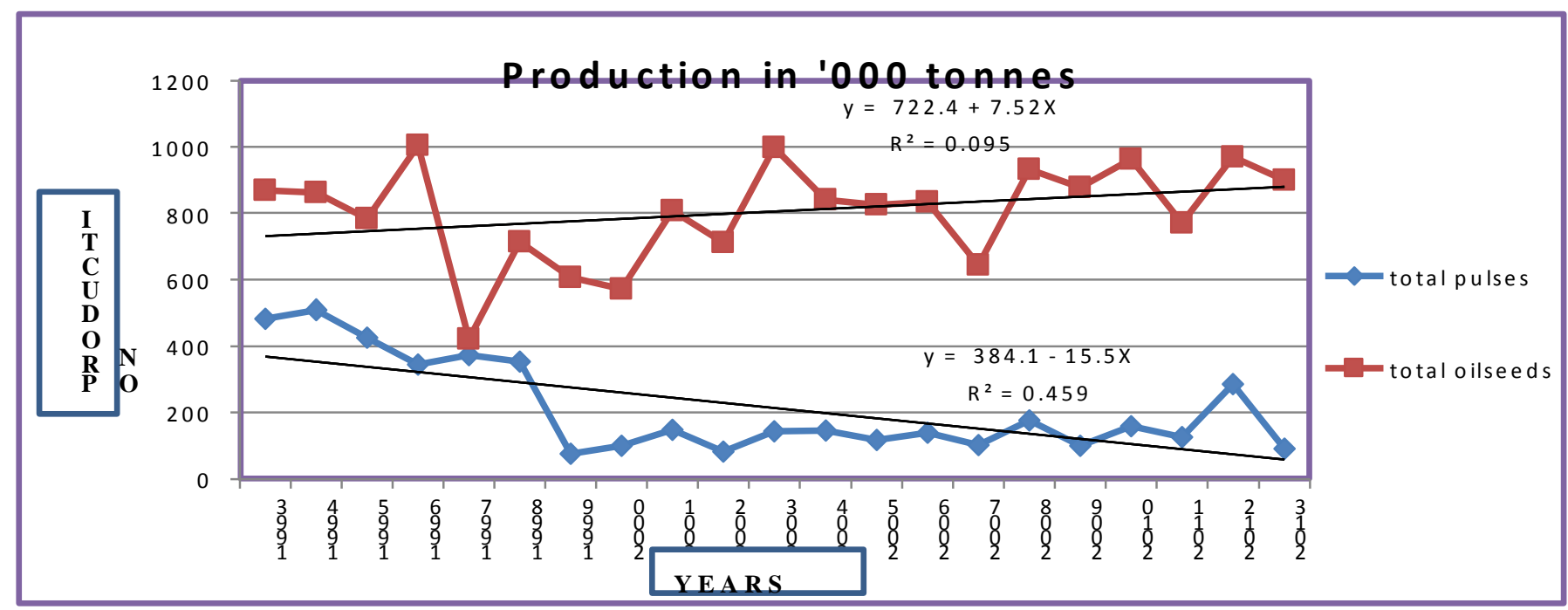

\section{Production pattern}

Table 3 shows a remarkable increase in food grains production visible in Haryana since 1993-94. The compound growth rate of paddy was $2.94 \%$ during the time period 1993-2003 and $2.80 \%$ during 2003-13. The compound growth rate of wheat was almost same in both the time periods. Although, the total production of food grains is increasing continuously, in case of pulses it is declining. A negative growth rate is shown in case of jowar, maize, barley, gram, total pulses and cotton during the time period 1993-2003, while there has been a negative growth rate in case of maize, gram and sugarcane in the second decade, i.e., 2003-2013. The overall positive growth rate, i.e., from 1993-94 to 2013-14 has been noticed in almost all the crops except maize, gram, total pulses and sugarcane. Some crops showed increased production in the study period irrespective of change in area like cotton, rapeseed mustard, jowar, bajra, etc. In case of cotton this change has occurred due to introduction of Bt cotton while in jowar the reason is its property of extreme drought tolerance. In case of bajra hybrids played a major role in increasing production. It is clear from Table 4 that the compound growth rate of yield of different crops in Haryana. The productivity of each crop has increased during the time period 2013-14. It is essential to mention that yield of jowar, gram and ultimately total pulses have shown a mixed pattern of increase and decrease. For example, jowar has negative growth rate, i.e., $-1.44 \%$ during 1993-2003 while the same crop has a positive growth rate of $8.63 \%$ during the next time period, i.e., 2003-13. This crop has an overall positive growth rate of $5.89 \%$ during the whole study period. Similarly, gram has $-3.46 \%$ growth rate during first decade and a positive growth of $4.45 \%$ in the next decade and overall $0.17 \%$ during the study period. The overall growth rate of each crop is a positive value except total pulses (Figs. 3 and 4).

\section{Conclusions and policy implications}

It was found that paddy and wheat are having highest area in kharif and rabi season. Better growth in production of paddy and wheat is mostly on account of their area growth. Among Rabi crops wheat is taking away area from gram and sugarcane while among Kharif 
crops paddy is taking away area from bajra and other crops (Singh et al., 2015). This is due to higher yields, favourable price policy, availability of inputs at affordable prices as well as assured irrigation facilities, etc. In order to reduce area under paddy and wheat, there is an urgent need to ensure parallel facilities for alternative crops. Without firm policy reforms in favour of alternative crops, crop diversification will remain an elusive goal in Haryana and persist as an issue which will be debated on different for a without any concrete outcome. For cotton, the state has proposed that Cotton Corporation of India be asked to carry out MSP operations in all cotton markets in the state. Support of textile industries is also required for enhancing cotton production. Designated markets for cotton need to be upgraded under the Technology Mission. For sugarcane, the crushing season of at least 180 days for sugar mills need to be ensured through developing early maturing varieties and sick cooperative sugar mills need to be revived. Though, water requirement of sugarcane is high, it is important for the state due to local market demand and long product shelf life. There is need of modernizing as well as capacity enhancement of existing sugar mills in the state.

In Haryana, horticultural crops are getting popular among farmers due to government support under the National Horticulture Mission (NHM). But, full potential could not be tapped due to severe constraints in infrastructural and marketing facilities. In order to make mission more effective, following policy measures are suggested:

(1) To promote shorter gestation period of vegetable and fruit crops through research and development

(2) Timely availability of good quality planting material

(3) Motivating farmers to adopt latest technology for growing these crops.

\section{References}

McCord P.F., Cox Michael, Harsh M.S. and Evans Tom (2015).Crop Diversification as a Smallholer Livelihood Strategy within Semi-arid Agricultural Systems near Mount Kenya, Land Use Policy (42): 738-750.

Raj, Roop and Gupta, Dr. Surendar, 2013.Non-Conentional Energy Sources in Agriculture in Haryana (India).International Journal of Science and Research (IJRS), 4(6): 2665.

Singh, A. (2011). Diversification in Agriculture, Retrieved from www.eoearth.org/view/article/151757

\section{How to cite this article:}

Sunita, Sanjay, Kavita, Jitender Kumar Bhatia and Mehta, V.P. 2017. Changing Pattern of Area, Production and Productivity of Principal Crops in Haryana. Int.J.Curr.Microbiol.App.Sci. 6(12): 1654-1661. doi: https://doi.org/10.20546/ijcmas.2017.612.186 